\title{
Transformational Leadership Behaviour Skills of Presidents and Vice-Presidents of State Universities and Colleges in the Philippines
}

\author{
Thelma D. Manansala \\ Bataan Peninsula State University, Bataan, Philippines
}

\begin{abstract}
This study was conducted to assess the transformational leadership behaviour skills of presidents and vice-presidents of state-owned universities and colleges in Region III. Globalization and technological change challenge school administrators to produce workforce who could meet global standards who are flexible in responding creatively and independently the different under varying conditions to the changing world. The study used the combination of quantitative and qualitative method of research. The main tool for data gathering was the survey questionnaire. An interview was also conducted that added up to the veracity of the responses obtained from the questionnaire. The respondents of the study were the presidents and vice-presidents of state universities and colleges of higher learning institutions in the eight provinces of Region III. The transformational leadership of these State Universities and Colleges (SUC) leaders were rated by the directors of different offices, the deans, and college coordinators of different colleges, the supreme student council officers duly recognized by the university/colleges, and the presidents and vice-presidents themselves. The respondents were selected using universal sampling due to the limited number of respondents. The main tool for data analysis is the frequency, percentage, means, standard deviation, regression analysis, and multiple correlations. Finding of the study showed that the state-owned universities and colleges' presidents and vice-presidents received a very satisfactory rating in their transformational leadership skills. Relevant trainings attended by SUC leaders to hone their leadership skills were found to be most significantly affecting the transformational leadership.
\end{abstract}

Keywords: Philippines, Region III, state university and colleges, transformational leadership behavior skills, total quality management practices

The world of work is in constant flux, continually redesigning itself so as to meet the exigencies of the present with an eye of the future. The mandate of tertiary education is the creation of an employable workforce. To achieve this tertiary education needs to adjust and quickly respond to globalization, technological change, and new forms of works and organizations.

In the Philippines, higher educational learning is the most extensive in the world. It is composed of 110 public chartered colleges and universities and 1,280 private colleges and universities [Philippine Commission on Educational Reform (PCER) Report, 2009]. The mandates of these universities and colleges are to produce a

Corresponding author: Thelma D. Manansala, Ed.D., Associate Director of Auxillary and Entrepreneurial Services, Cluster Chair of the Mathematics Department, Technical and Research Specialist, Bataan Peninsula State University; research fields: education leadership, social and behavioral sciences. E-mail: enthelgem@yahoo.com. 
kind of labor force which will help alleviate the worsening economic condition not only in our country but the whole world in particular. School of higher education needs to produce a labor force that will be globally competitive and supply where demand is great.

For the past decades, education especially in the higher institutions of learning was strictly scrutinizing to find out possible reasons and remedies to affect our ailing educative system. Numerous and countless reforms of policies and programs were formulated and instituted to remedy these ills and upgrade the quality of our graduates. And yet at this phase of fast changing technologies and innovations, the Philippine education system was far behind our Asian counterparts in terms of educational outputs. Quality education seems to be an impossible dream that each in the school of higher learning aimed to achieve at the end of the day. Quality has been the word of mouth in the 21st century and yet the Philippine educational system is depreciating and worsening. As mentioned by Abad (2004) in his keynote address in the national educators congress that there is crisis in the Philippine education. He was also noted saying that our schools must be transformed to become a noble institution of learning.

State Universities and Colleges (SUC) need leaders who have good visioning skills. They could vision reforms and programs that will bring positive effect into the educative process. Leaders, who would influence, motivate, and inspire people to create vision and achieve it. The challenge to these leaders is to build quality institutions in creating the passion, the obsession, and the thirsts with quality involving all in the organization.

Another challenge faced by leaders of higher institutions of learning particularly the SUCs is to create a quality that penetrates to the smallest elements, processed systems of instructions. Accordingly, the leaders of a college or university are guide to quality transformation. It is a common experience in the educative process that under the same set of rules and regulations, with the same set of teachers and non-teaching staff, and with the students from similar background education degenerates or maintains a "status quo" or rises to prominence with a change of educational leaders.

As noted by Bass and Yamarino (1990), "Today's networked, independent culturally diverse organization requires transformational leaders to bring out in followers their creativity imaginations and best efforts". Bass (1990) once wrote that transformational leadership is a kind of leadership where leaders motivate others to do more than what they really are originally expected to do by raising a sense of importance and value to their tasks, by going beyond self-interest for the sake of the team or organization.

\section{Transformational Leadership}

As opined by Northouse (2004), "leadership as a process whereby an individual influence a group to achieve a common goal". To be an effective leader, the manager must influence his associates in appositive way to reach the goal of the organizations, giving focus on the optimum use of individual strength, capabilities, matching them to an appropriate role while helping them to take responsibilities for developing areas that will make a positive difference.

According to Kotter (1999), "The fundamental purpose of leadership is to produce change especially non-incremental change with the fundamental purpose of management to keep the current system functioning". So leadership is distinguished by appealing to the values of the follower by satisfying the basic human needs for achievement, a sense of belonging, recognition, self-esteem, the ability to light up and maintaining the desired state to ones ideals. Leading an institution to maintain status quo and leading an instruction to foster continuous growth and development are two different paradigms altogether. In the learner, leadership has to continuously 
evolve and unfold to its full potential. Hence, the emphasis is on transformational leadership. Transformational leadership emphasizes on the capacity to engage others in commitment to change (Abu-Duhou, 1999).

Similarly, Bass (2000) pointed out that transformational leadership is a kind of leadership whose goal is to inspire followers, to share the leader's values and connect it with the leader's vision. This connection is manifested through the genuine concern the leaders have for their followers and the followers giving their trust in return. Transformational leaders exhort followers to support the leader's vision by sharing ideas, imagination, talents, and labor to reach an agreement and to attain virtuous goals for the good of the leaders, followers, and organizations. Both leaders and followers rise above their self-interest for the betterment of all both achieves genuine satisfaction.

Today's networked, interdependent, culturally diverse organization requires transformational leadership to bring out in their followers their creative imaginations and best efforts. To be effective now and in the future, almost all of the leadership literature agreed that people could not be treated like sheep, blindly herded from place to place. Their expertise, experience, and intuition need to be encouraged, not stifled if challenging situations are to be negotiated successfully (Avollo \& Bass, 1993).

The same authors have spoken that transformational leadership should fuse the leader's vision so strongly into the followers that both are motivated by high moral values and ethical principles. The process raises them above self-interest to perform their exacting duties even to the ultimate sacrifice for the good of the entire organization.

\section{Transformational Leadership Behavior Skills}

\section{Visioning Skills}

Visioning skills involve those processes of communications, which lead people to want to be a part of an exciting and involving vision. When effectively internalized, such a vision provides inspiration and a direction to behavior. However, commitment to a vision occurs only when people feel that they are actively involved in creating it. The skills associated with vision entail creating mental and verbal pictures of the desirable future states in which others can participate and feel they have a necessary part to play (Byrd, 1987).

By creating a vision, the leader provides a means for people to develop commitment, a common goal around which to rally, and a way for people to feel successful. To start, there must be a declaration of what the future will be. A powerful declaration of vision can create a quantum leap in an organization's performance. It is the willingness to put you on the line and say what the future will be instead of being mercy of whatever the future will bring. This vision may serve as an opportunity to uncover what is missing between where they are and where they want to be. By declaring the vision, transformational leaders open path for people to place themselves in an area where they will be motivated to give their best not only for their own good but for the good of the entire organization.

Welch (1997) quotes "Leaders inspire people with clear vision of how things can be done better". The best leader does not provide a step-by-step instruction manual for workers. The best leaders are those who come up with new ideas, and articulate a vision that inspires others to act. The transformational leaders hence ensure that in creating a vision, it must be founded on a value system which unifies, integrates, and harmonizes the values and purpose of most of those concerned as well as that of the business.

\section{Anticipating Skills}

Transformational leaders entail "projecting consequences, risks and trade-offs (having foresight), actively 
seeking to be informed and to inform (scanning and communicating) and proactively establishing relationships (building trust and influence)". Anticipatory skills include the ability to see and understand patterns of environmental forces to know when to reassess or challenge assumptions, to see the value and limitations of alternatives recognize "hybrid" behaviors and to balance human and technical interest (Cushman \& Cahn 1995).

\section{Value Congruence Skills}

Transformational leaders as noted by Yorges, Weiss, and Strickland (1999), built trust in their leadership and their attainability of their goals through an image of seemingly unshakeable self-confidence, strengths of moral conviction, personal example of self-sacrifice, and unconventional tactics of behaviors. These involve those processes in articulating values, which can give appropriate direction to organizational activities. Values are often internalized so deeply that they define personality and behavior. Transformational leaders must be in touch with workers, investors, and consumers values and be able to articulate and appreciate congruence among them.

Value congruence skills entail knowing, understanding, articulating, and integrating these values into workable system. Shared values are what engender trout and link an organization together. Shared values are also identifying by which an organization is known throughout the business areas. These values must be stated as both operate objectives and individual values. Every organization and every leader will have a different set of values that are appropriate in any organizational setting. Find people who are competent and really bright, but more importantly, people who care exactly about the same thing you care about (Edwards \& Cable, 2009).

As many researchers found out, one of the main reasons why organizations fail is lack of value congruence. Lack of shared values among organizations may eventually lead to lack of trust between and among the management and the employee, blame culture exist, focus on problems not opportunities and more importantly, people lose confidence in their leaders.

\section{Empowering Skills}

As according to Wagner, Parker, and Christiannsen (2003), empowerment is delegation and accountability, a top down process where senior leaders articulate a vision and specific goals, and hold followers responsible for achieving them. Others believed empowerment as more of bottom up approach that focuses on intelligent risk taking, growth change, trust, and ownership; followers act as entrepreneurs and owners that question rules and make intelligent decisions. Leaders tolerate mistakes and encourage cooperative behavior in this approach of empowerment.

People are the most important asset of the organization. Technologies, products, and structures can be copied by competitors. No one can, however, match the highly charged, motivated people who care. People are the firm's repository of knowledge and they are central to the company's competitive advantage. Well-educated, coached, and highly-motivated people are critical to the development and execution of strategies, especially in today's faster-paced, more perplexing world, where top management alone can no longer assure the company's competitiveness.

People tend to rise on the occasion that someone truly believes in them. A preacher one said if you place an A on a person's head, they will give you an A, but if you put a C on their head, they will give you a C, no higher. Many times people are looking for someone to be interested in them and hold accountability to. When they find this individual, they will produce. It is essential during a cultural transformation that each person in 
the firm has someone that believes in them and is counting on them to succeed (Kotelnikov, 2007).

$\mathrm{He}$ also wrote that empowerment is the oil that lubricates the exercise of learning. Talented and empowering human capital is becoming the prime ingredient of organizational success. A critical feature of successful teams, especially in knowledge-based enterprises is that they are invested with a significant degree of empowerment or decision-making authority.

As according to Katzenbach and Smith (2005), for leaders to truly empower their employees, they must delegate leadership and decision-making down to the lowest level possible. He also stressed that empowerment help employees learn more about their job. This knowledge and skills gain increases the intellectual capital of the industry and can be a competitive advantage in moving ahead. Empowerment of employees results in increased initiative, involvement, enthusiasm, innovation, and speed, all in support of the company's mission. The word empowerment means to authorize, enable, and to permit. Defining and encouraging empowerment is the job of transformational leaders.

\section{Self-Understanding Skills}

Self-understanding skills involve recognition of one's own strength and weaknesses and the location of others who can synergize with the strengths and compensate for the weaknesses. Self-understanding skills entail the use of variety of tools to recognize one's strength and weaknesses, realizing that ego strength is a requirement of leadership, but must be moderated by help from others, involve recognition of one's own strength and weaknesses and location of others who can synergize with the strengths and compensate for the weaknesses. Self-understanding skills entail the use of variety of tools to recognize one's strengths and weaknesses, realizing that ego strength is requirement of leadership but must be moderated by help from others (Gunter, 2001).

The capacity for self-understanding presupposes the capacity to understand others specifically the members of the organization. Common sense tells us that it is easy to understand ourselves than understand other people. Understanding of oneself comes out of constant interactions with physical, cultural, and interpersonal environment. It is characterized by continuous search out of communalities of experiences to unify and make coherent that an individual may have in common with someone else. It requires unending negotiations and regenerations of the meaning of experiences to one's existence.

The same author believed that to be an effective manager, you must know yourself, your strengths, your weakness, and those of the people around you. You must know your objective and have a plan on how to achieve them. You must build a team of people that share your commitment to achieve those objectives and you must help each team member to achieve their best which will be able to attain a common goal.

No one can be able to manage and lead others unless they are able to understand themselves. Understanding oneself is the skill needed to correctly manage actions, words, demeanor, attitude, image, and its impact on others.

SUC administrators as education leaders should inspire their followers to share their values and connect to them to the attainment of their vision. This connection is manifested through the genuine concern of leaders have for their followers and the followers giving their full trust in return. They can encourage their followers to support their vision by sharing ideas, imaginations talents and labors to reach agreement to attain virtuous goals for the good of the leaders, the followers and for the whole organization as well. SUC administrators are believed to be the frontrunners in bringing total change in the entire educative system so as to make education 
of higher learning comparable to some of its Asian counterparts. They were believed to lead the educational path toward a better education in the third millennium.

The leadership performance of SUC presidents and administrators has been considered as a determinant for a total quality performance of higher education institutions. We may come up with the best educational reforms in the world, but if education leadership is weak, the performance of the institution will suffer. Many times, institutional performance is a matter of choosing the appropriate leadership styles that best fit SUC's administrator so that higher education institutions will move forward and be comparable to its Asian counterparts.

In today's generation, SUC presidents and administrators are not just meant for social development of an individual, they also play a vital role in the economic development of the nation. They are leaders who can articulate an appealing vision of the future, challenge their followers with high standards, talk optimistically and with enthusiasm, provide encouragement, and identify what needs to be done.

It is in the above context that the researcher is motivated to undertake this study.

\section{Methodology}

The researcher utilized the combined method of qualitative and quantitative method of research, particularly using the survey questionnaire as the main tool for data gathering. The survey questionnaire consisted of two parts: The first part focused on the demographic profile of the SUC presidents and vice-presidents, namely: age, gender, educational attainment, faculty rank, seminars attended relevant experience, and membership to professional organization. The second part assessed the transformational leadership behavior skills of SUC presidents and vice-presidents in terms of visioning skills, anticipating, value congruence, empowerment, and value orientation. The study used universal sampling in selecting the required number of samples due to the limited number of respondents for SUC presidents and vice-presidents together with the officials of the university and student council officers. The transformational leadership skills were rated using the Likert scale with the following indicators and verbal interpretations:

$\begin{array}{ll}\text { Scale } & \text { Descriptive equivalent } \\ 5 & \text { Outstanding } \\ 4 & \text { Very satisfactory } \\ 3 & \text { Satisfactory } \\ 2 & \text { Fair } \\ 1 & \text { Poor }\end{array}$

Indicator

The activity was observed $85 \%-100 \%$ practiced at all times. The activity was observed $66 \%-84 \%$ practiced at all times The activity was observed $33 \%-64 \%$ practiced at times. The activity was observed $15 \%-32 \%$ practiced at times. The activity was observed $1 \%-14 \%$ practiced at times.

\section{Population and Sample of the Study}

Table 1 gives the frequency distribution of the respondents.

This group of respondents was divided into three classes of raters: The school administrators comprise of the university president and vice-presidents, the middle level managers comprise of the deans and directors, and the third group of rater is the supreme student council officers. The university president and vice-president were asked to assess themselves on the extent of how they practiced transformational leadership skills to balance the assessment made by their subordinates. The second raters were called the middle level managers, comprising of the directors of different offices, the deans, and the coordinators of the different colleges. The middle level managers served as the alter ego of the university presidents and vice-presidents. Hence, they are expected to command their respective offices in accordance to the directives from these higher officials. And the third 
group of raters was the supreme student council of the university. The supreme student council was the highest governing body of the student organization and was duly recognized by the university. This was composed of students who were duly recognized as the official students of the university (Student hand book, 2010).

The locales of the study were the selected state universities and colleges in the Philippines, particularly in Region III or Central Luzon. These include Tarlac State University in Tarlac Province, Ramon Magsaysay Technological University in Zambales Province, Pampanga Agricultural Colleges in Pampanga, Bulacan State University in Bulacan, Don Honorio Ventura State University in Pampanga, Central Luzon State University and the University of Science and Technolgy both in Nueva Ecija.

Table 1

Frequency Distribution of the Respondents

\begin{tabular}{llll}
\hline & $\mathrm{F}$ & $\mathrm{n}$ & Percentage (\%) \\
\hline University presidents & 7 & 7 & 100 \\
University vice-presidents & 25 & 23 & 92 \\
Directors & 116 & 111 & 96 \\
Deans of various colleges & 52 & 48 & 92 \\
Student council officers & 58 & 45 & 78 \\
Total & 258 & 234 & 91 \\
\hline
\end{tabular}

\section{Result and Discussion}

\section{Age}

As shown in Table 2, it reveals that 20 out of the 30 or $66.67 \%$ of SUC administrators have the age bracket ranging from 56 to 60 years old, seven or $23.33 \%$ age bracket of $51-55$ years old, and only three respondents or $10 \%$ aged 60 years and above. The computed mean age is 57 which indicates that they are in their late prime age. Findings tend to reveal that since the SUC administrators were in their prime age, they could be classified as older managers. Anderson (2000) stressed that older managers tend to focus their management style on the soft qualities of management which is human relations.

\section{Gender}

In terms of gender, the same table reveals that 21 out of the 30 respondents are male and only nine are female. This finding indicates that managerial position is still a man's job even in the educative process. Noteworthy to mention also is that out of the seven SUC presidents, there is only one lady president. Eagly and Carli (2003) noted that writers identified four general factors that explain the shift toward more women leaders. First is that women have changed themselves. This is very evident in the ways women's aspirations, attitudes have become similar to the traits of male over time. Women's self-respect, assertiveness, dominance, and masculinity are the values that women place on characteristics of work such as freedom, challenge leadership, prestige, and power. The second factor is that leadership roles have changed, particularly with regards to trends, toward less stereotypically masculine characterization of leadership. The third, organizational practices have changed. A large part of this could be attributed to legislation prohibiting gender-based discrimination at work, as well as changes in organizational norms that put priority on input than the old by network. And lastly the fourth, organizational cultures have changed. This is evident example of the symbolic message often initiated by appointment of women to important leadership position, one representing a departure from the past practice and signally commitment to progressive change. 


\section{Educational Qualifications}

Posted also in Table 2 is on educational qualification. It shows that 27 out of the 30 respondents or representing $90 \%$ of the SUC administrators graduated either Doctors of Education (Ed.D.) or Doctors of Philosophy (Ph.D.) degree and only three or 10\% were noted in the process of completing their doctor's degree. In general, most SUC administrators are highly qualified in terms of their educational qualification. This result could perhaps be attributed to the strict implementation on the educational qualifications of SUCs leaders that educational requirements for university administrators must be doctorate degree. As noted by Vecchio and Boatwright (2002), both writers believed that professional preparation for potential education leaders should be based upon a broad background of general education. Similarly, Hernez-Broom and Hughes (2004) urged the proliferation of education leadership in the context of work itself. The goal of studying is no longer to make the grade or earn the diploma, but rather to understand what is happening around, to develop a personally meaningful sense of what one has experienced all about. Hogan and Warrenfeltz (2003) believed that people who lead in the modern organizations need to be engaged in a never-ending learning process of "learning to learn from experiences".

Table 2

Personal Profile of the SUC Administrators

\begin{tabular}{|c|c|c|}
\hline Variables & $\mathrm{f}$ & Percentage $(\%)$ \\
\hline \multicolumn{3}{|l|}{ Age } \\
\hline $51-55$ years old & 7 & 23.33 \\
\hline $56-60$ years old & 20 & 66.67 \\
\hline Above 60 years old & 3 & 10 \\
\hline Total & 30 & 100 \\
\hline Mean & 57.77 & \\
\hline \multicolumn{3}{|l|}{ Gender } \\
\hline Male & 21 & 70 \\
\hline Female & 9 & 30 \\
\hline Total & 30 & 100 \\
\hline \multicolumn{3}{|l|}{ Educational attainment } \\
\hline With units in doctoral & 3 & 10 \\
\hline With doctor or Ph.D. degree & 27 & 90 \\
\hline Total & 30 & 100 \\
\hline \multicolumn{3}{|l|}{ Faculty rank } \\
\hline Below professor & 24 & 80 \\
\hline Professor & 6 & 20 \\
\hline Total & 30 & 100 \\
\hline \multicolumn{3}{|l|}{ Relevant trainings } \\
\hline $0-5$ seminars & 17 & 56.67 \\
\hline $6-10$ seminars & 13 & 43.33 \\
\hline Total & 30 & 100 \\
\hline \multicolumn{3}{|c|}{ Years in the service as administrator } \\
\hline $0-5$ & 16 & 53.33 \\
\hline $6-10$ & 14 & 46.67 \\
\hline Total & 30 & 100 \\
\hline
\end{tabular}




\section{Faculty Rank}

In terms of faculty rank, Table 2 indicates that 24 or $80 \%$ of SUC administrators did not enjoy the faculty rank of professors and only six respondents or $20 \%$ preferred the faculty rank of a professor. This finding tends to imply that the administrators opted the salary grade assigned to a president and vice-president which is higher than their faculty rank.

\section{Relevant Training}

Table 2 also reveals that 17 or $56.67 \%$ of SUC administrators have attended relevant seminars and trainings at an average of $0-5$ seminars and trainings, while 13 or $43.33 \%$ averaged at $6-10$. This finding implies that SUC administrators still welcome opportunities for them to grow professionally and uphold lifelong learning. They uphold that seminars and trainings would further develop their leadership skills in the context of life like situation. It would expose them to focus on strategic planning, public relations, and interpersonal skills. It would also improve their scientific attitudes and methodologies in finding better solutions to some organizational problems in the most effective and efficient ways.

\section{Relevant Experience}

Similar table discloses that 16 SUC administrators have been in their administrative post for $0-5$ years and 14 of them have served for 6-10 years. In general, it could be assumed that more than one half of the respondents were on their first term in serving their present post. Also, Rynes, Bartunek, and Daft (2010) emphasized that experience implies knowledge. The longer the time a manager stays in the work place will enable him to master his line of craft by the heart. The three researchers further exposed that different opportunities in developing leadership skills include knowing the technical side of work and more importantly gaining flexibility in dealing with people which is considered as the most complex part of the organization.

\section{Transformational Leadership Behaviour Skills of SUC's Presidents and Vice-Presidents}

Analyzing result of Table 3 displays that the grand mean rating for SUCs' visioning skill was 4.73, indicating that the SUC leaders gave themselves an outstanding performance. Result of the study manifests that SUC had the vision to adopt organizational changes that will benefit the entire academe. Attainment of such implies a collaborative effort: Their masterpieces could be measured on how they were able to influence more people in the organization to raise themselves against dogmatic practices and to make sacrifices that will contribute to the organizational development.

As for the middle level managers, they gave their SUC leaders a grand mean rating of 3.72 with a descriptive equivalent of very satisfactory. The middle level managers felt that their SUC administrators tend to inspire and ignite the spirit of their followers to maximize their potentialities, however, this group of respondents perceived that these school leaders were unable to evoke strong feelings into their followers to do more than they could toward the attainment of the university's vision and mission.

On the other hand, the student council rated the visioning skills of their SUC presidents and vice-presidents to be satisfactory as noted by the grand mean rating of 3.41. For the student council officers, SUC administrators need to heighten emotional level of their followers so as to increase level of efficiency and performance. This finding conforms to what was stated by Anderson (2000) that as one gets older, leadership skills deteriorate on association with the younger generations because of generation gap. Younger generations 
of leaders were more aggressive on implementing change while their older counterparts tend to focus more on the human qualities and soft qualities of organization.

Table 3

Transformational Leadership in Terms of Visioning Skill as Perceived by the SUC Administrators, the Middle Level Managers, and SSC (Supreme Student Council) Officers

\begin{tabular}{|c|c|c|c|c|c|c|c|c|c|}
\hline Transformational behavior skills & $\mathrm{X}_{1}$ & $\mathrm{DE}$ & $\mathrm{Sd}$ & $\mathrm{X}_{2}$ & $\mathrm{DE}$ & $\mathrm{Sd}$ & $\mathrm{X}_{3}$ & $\mathrm{DE}$ & $\mathrm{Sd}$ \\
\hline \multicolumn{10}{|l|}{ Visioning skills } \\
\hline 1. Looks ahead into constantly changing demand & 4.85 & $\mathrm{O}$ & 0.29 & 3.70 & VS & 0.44 & 3.40 & $\mathrm{~S}$ & 0.66 \\
\hline $\begin{array}{l}\text { 2. Leads members of the organization in the formulation and } \\
\text { revision of the university's vision and mission }\end{array}$ & 4.78 & $\mathrm{O}$ & 0.27 & 4.0 & VS & 0.78 & 3.41 & $\mathrm{~S}$ & 0.09 \\
\hline $\begin{array}{l}\text { 3. Inspires and motivates members of the organization to } \\
\text { perform their work in accordance with the university's vision } \\
\text { and mission }\end{array}$ & 4.62 & $\mathrm{O}$ & 0.36 & 3.6 & VS & 0.37 & 3.77 & $\mathrm{~S}$ & 0.94 \\
\hline $\begin{array}{l}\text { 4. Directs members of the organization to act based on they } \\
\text { want the organization to be }\end{array}$ & 4.71 & $\mathrm{O}$ & 0.35 & 3.73 & VS & 0.63 & 3.41 & S & 0.99 \\
\hline $\begin{array}{l}\text { 5. Unites people in the face of something at stakes which you } \\
\text { stand for }\end{array}$ & 4.71 & $\mathrm{O}$ & 0.31 & 3.81 & VS & 0.67 & 3.45 & $\mathrm{~S}$ & 0.87 \\
\hline $\begin{array}{l}\text { 6. Inspires members to come up with new ideas to come up } \\
\text { ideas that will prove beneficial to the entire organizations }\end{array}$ & 4.71 & $\mathrm{O}$ & 0.35 & 3.5 & VS & 0.50 & 3.43 & $\mathrm{~S}$ & 1.0 \\
\hline Grand mean & 4.73 & $\mathrm{O}$ & 0.13 & 3.72 & VS & 0.28 & 3.41 & S & 0.54 \\
\hline
\end{tabular}

Notes. $\mathrm{X}_{1}$ - mean rating of SUC administrators; $\mathrm{X}_{2}$-mean rating of middle level managers; $\mathrm{X}_{3}$-mean rating of the SSC officers; $\mathrm{DE}$ - descriptive equivalent of the mean; $\mathrm{Sd}$ — standard deviation; O — outstanding; VS - very satisfactory; S- satisfactory.

\section{Anticipating Skills}

On anticipating skills, the SUC administrators gave themselves an outstanding performance as shown by the grand mean of 4.67. Highest rating of 4.83 interpreted as outstanding was on the item "possesses great potential for revitalizing and refueling of members as they perform their work". Lowest rating of 4.64 interpreted as outstanding was observed on the item facilitates future training opportunities among members of the organization. This is an indication that SUC administrators continue to motivate and inspire their members to grow professionally and personally to make themselves adoptive to organizational changes. They set high expectations which boost the self-confidents of followers by expressing confidence in their abilities and providing ongoing encouragements and supports. However, with the scarcity of budget that SUCs received from the government, training opportunities and career advancement of college instructors were not prioritized and on selective basis (see Table 4).

On the other hand, the middle level managers perceived the SUC administrators as experts in implementing strategies of controlling measures to prevent the occurrence of future problems as this statement was given the highest mean rating of 3.80 interpreted as very satisfactory. They knew that problem is inevitable fact in the organization and leadership role. SUC administrators pictured the future of the organization and at the same time adopted measures of programs that will minimize if not totally eradicate occurrence of future problems. Moreover, successful resolving of problems becomes an important skill in leadership and management practices. This group of raters gave a very satisfactory mark in the anticipating skills of SUC administrators as evident by the grand mean of 3.67.

However, the student leaders gave a satisfactory rating as shown by the computed mean of 3.40 . The student leaders gave the lowest mark on "plans programs and policies ahead of time". The student leaders strongly felt that they were not given the opportunity to sit down with these school administrators together with 
other school officials in the planning of programs of activities that will directly benefit all the students. As mentioned earlier, SUC administrators have good visioning skills in the prediction of future problems that may arise in the daily operations of the organization, and the student leaders like the middle managers perceived that the SUC administrators have devised mechanisms to minimize if not totally eradicate occurrence of conflict in the organization. For this group of raters, they gave a satisfactory rating in this aspect of transformational leadership behavior skills as shown by the grand mean rating of 3.40 .

Table 4

Transformational Leadership in Terms of Anticipating Skills as Perceived by the SUC Administrators, the Middle Level Managers, and SSC Officers

\begin{tabular}{|c|c|c|c|c|c|c|c|c|c|}
\hline Transformational behavior skills & $\mathrm{X}_{1}$ & $\mathrm{DE}$ & $\mathrm{Sd}$ & $\mathrm{X}_{2}$ & $\mathrm{DE}$ & $\mathrm{Sd}$ & $\mathrm{X}_{3}$ & $\mathrm{DE}$ & Sd \\
\hline \multicolumn{10}{|l|}{ Anticipating skills } \\
\hline 1. Plans programs and policies ahead of time & 4.70 & $\mathrm{O}$ & 0.29 & 3.73 & VS & 0.39 & 3.32 & $\mathrm{~S}$ & 0.74 \\
\hline $\begin{array}{l}\text { 2. Forecasts events based on the observations and experiences } \\
\text { from current situations and events }\end{array}$ & 4.75 & $\mathrm{O}$ & 0.22 & 3.72 & VS & 0.28 & 3.36 & $\mathrm{~S}$ & 1.01 \\
\hline $\begin{array}{l}\text { 3. Implements strategies of controlling measures to prevent the } \\
\text { occurrence of future problems }\end{array}$ & 4.74 & $\mathrm{O}$ & 0.18 & 3.80 & VS & 0.63 & 3.48 & $\mathrm{~S}$ & 0.93 \\
\hline $\begin{array}{l}\text { 4. Facilitates training for future opportunities among members } \\
\text { of the organization }\end{array}$ & 4.64 & $\mathrm{O}$ & 0.29 & 3.73 & VS & 0.52 & 3.39 & $\mathrm{~S}$ & 0.78 \\
\hline $\begin{array}{l}\text { 5. Develops long range plans for the purpose to solve future } \\
\text { problems }\end{array}$ & 4.80 & $\mathrm{O}$ & 0.20 & 3.68 & VS & 0.61 & 3.43 & $\mathrm{~S}$ & 0.73 \\
\hline $\begin{array}{l}\text { 6. Possesses great potential for revitalizing and refuelling of } \\
\text { members as they perform their work }\end{array}$ & 4.83 & $\mathrm{O}$ & 0.21 & 3.72 & VS & 0.63 & 3.41 & $\mathrm{~S}$ & 0.97 \\
\hline Grand mean & 4.67 & $\mathrm{O}$ & 0.34 & 3.67 & VS & 0.44 & 3.40 & $\mathrm{~S}$ & 0.57 \\
\hline
\end{tabular}

Notes. $\mathrm{X}_{1}$-mean rating of SUC administrators; $\mathrm{X}_{2}-$ mean rating of middle level managers; $\mathrm{X}_{3}-$ mean rating of the SSC officers; $\mathrm{DE}$ - descriptive equivalent of the mean; $\mathrm{Sd}$ — standard deviation; $\mathrm{O}$ - outstanding; VS—very satisfactory; $\mathrm{S}$ - satisfactory.

\section{Value Congruence}

The SUC administrators gave themselves an outstanding rating as shown by the grand mean rating of 4.76. SUC administrators gave themselves an outstanding performance on the item "builds a work culture founded on organization's core value" with the highest mean rating of 4.87. This implies that as leaders, they stay upfront in the processes of articulating values, which can give appropriate direction to organizational activities. The leader's personal values may be one of the most important determinants of how power is exercised or constrained. In addition, Gardener (1990) stressed the centrality and importance of moral dimension of leadership. He further stressed that leaders who do not behave ethically do not demonstrate true leadership (see Table 5).

The middle level managers gave their superiors a very satisfactory rating as shown by the computed mean of 3.67 with strong emphasis that in the formulation of their annual plan, it must include activities that will enhance value formation and revitalizing programs of their constituents. Middle level managers understand the importance of value formation and revitalizing programs for the upliftment of the worker's morale and values.

The student council officers rated the administrators as satisfactory with the mean rating of 3.36 . This group of respondents emphasized the use feedback as a tool for member's professional and personal development. This is an indication that SSC officers became aware on the importance of performance appraisal as one of the main tool in identifying instructors' points of strength and that need further enhancement. The lowest rating was noted on "recognizing accomplishments of members through rewards and citations" as noted by the mean of 3.22 interpreted as satisfactory. Student leaders observed that instructors and other members of 
the academe were not given proper recognition for exemplary performance. Although there were some observed mechanisms used to evaluate members' efficacy in the advancement of the entire organization, but they were not given proper recognitions and commendations from the administrators.

Perhaps, the most important challenge to SUC administrators is to face varieties of challenges into their own value system and the value system of the people under their leadership. Interacting with individuals and groups holding divergent and conflicting values will be an inevitable fact of life.

Table 5

Transformational Leadership in Terms of Value Congruence as Perceived by the SUC Administrators, Middle Level Managers, and SSC Officers

\begin{tabular}{|c|c|c|c|c|c|c|c|c|c|}
\hline Transformational behavior skills & $\mathrm{X} 1$ & $\mathrm{DE}$ & $\mathrm{Sd}$ & $\mathrm{X} 2$ & $\mathrm{DE}$ & $\mathrm{Sd}$ & $\mathrm{X} 3$ & $\mathrm{DE}$ & $\mathrm{Sd}$ \\
\hline \multicolumn{10}{|l|}{ Values congruence } \\
\hline 1. Builds a work culture founded on organization's core value & 4.87 & $\mathrm{O}$ & 0.30 & 3.68 & VS & 0.51 & 3.43 & $\mathrm{~S}$ & 1.03 \\
\hline 2. Practices role model and ethical standard & 4.72 & $\mathrm{O}$ & 0.30 & 3.64 & VS & 0.56 & 3.39 & $\mathrm{~S}$ & 1.22 \\
\hline $\begin{array}{l}\text { 3. Recognizes accomplishments of members through rewards } \\
\text { and citations }\end{array}$ & 4.74 & $\mathrm{O}$ & 0.33 & 3.81 & VS & 0.61 & 3.22 & $\mathrm{~S}$ & 0.96 \\
\hline $\begin{array}{l}\text { 4. Uses feedback as a tool for member's professional and } \\
\text { personal development }\end{array}$ & 4.81 & $\mathrm{O}$ & 0.30 & 3.64 & VS & 0.59 & 3.48 & $\mathrm{~S}$ & 0.78 \\
\hline $\begin{array}{l}\text { 5. Encourages employees to hold values formation and other } \\
\text { related activities at least once a year for employees' } \\
\text { revitalization }\end{array}$ & 4.75 & $\mathrm{O}$ & 0.19 & 3.58 & VS & 0.53 & 3.30 & $\mathrm{~S}$ & 1.07 \\
\hline $\begin{array}{l}\text { 6. Encourages societal interactions among individual and } \\
\text { groups characterized by concern for others }\end{array}$ & 4.67 & $\mathrm{O}$ & 0.34 & 3.66 & VS & 0.61 & 3.32 & $\mathrm{~S}$ & 1.14 \\
\hline Grand mean & 4.76 & $\mathrm{O}$ & 0.29 & 3.67 & VS & 0.59 & 3.36 & $\mathrm{~S}$ & 1.03 \\
\hline
\end{tabular}

Notes. $\mathrm{X}_{1}$-mean rating of SUC administrators; $\mathrm{X}_{2}$-mean rating of middle level managers; $\mathrm{X}_{3}$-mean rating of the SSC officers; $\mathrm{DE}$ - descriptive equivalent of the mean; $\mathrm{Sd}$ — standard deviation; $\mathrm{O}$ — outstanding; VS—very satisfactory; $\mathrm{S}$ - satisfactory.

\section{Empowering Skills}

As according to Wagner et al. (2003), empowerment is delegation and accountability, a top down process where senior leaders articulate a vision and specific goals, and hold followers responsible for achieving them. Others believed empowerment as more of bottom up approach that focuses on intelligent risk taking, growth change, trust, and ownership; followers act as entrepreneurs and owners that question rules and make intelligent decisions. Leaders tolerate mistakes and encourage cooperative behavior in this approach of empowerment.

Table 6 discloses that the SUC administrators gave themselves the lowest rating on the item sharing power with members through delegation of work with a mean rating of 4.76. This is an indication that SUC administrators showed apprehension in sharing power with their members. The apprehension could be attributed to the fact that task could be delegated but not accountability.

Furthermore, they still need to find out if their subordinates were empowered or not. The conceptualization of empowerment has different implications for leaders and followers. It is in this conceptual confusion which has caused empowerment programs to fail in the organizations. The highest rating that SUC administrators rated themselves was on the statement gives total freedom to the subordinates that each knows their respective roles in the implementation of organization's mission and vision with the computed mean of 4.87 perceived as outstanding. Result of the study implies that though the SUC administrators, showed apprehension in sharing their powers to members, but they were still confident enough and put their full thrust into these employees that they were knowledgeable in their respective tasks or work assignments in the achievement of the organizational vision and mission. 
Table 6

Transformational Leadership in Terms of Empowering Skills as Perceived by the SUC Administrators, Middle Level Managers, and SSC Officers

\begin{tabular}{|c|c|c|c|c|c|c|c|c|c|}
\hline Transformational behavior skills & $\mathrm{X}_{1}$ & $\mathrm{DE}$ & $\mathrm{Sd}$ & $\mathrm{X}_{2}$ & $\mathrm{DE}$ & $\mathrm{Sd}$ & $\mathrm{X}_{3}$ & $\mathrm{DE}$ & $\mathrm{S}$ \\
\hline \multicolumn{10}{|l|}{ Empowering } \\
\hline 1. Shares power with members through delegation of tasks & 4.76 & $\mathrm{O}$ & 0.15 & 3.61 & VS & 0.56 & 3.84 & VS & 0.73 \\
\hline $\begin{array}{l}\text { 2. Gives members the flexibility to innovate, develop new } \\
\text { processes, techniques and procedures to accomplish } \\
\text { organizational goals and objectives }\end{array}$ & 4.83 & $\mathrm{O}$ & 0.18 & 3.55 & VS & 0.57 & 3.28 & S & 0.86 \\
\hline $\begin{array}{l}\text { 3. Helps organizational members to attain their personal } \\
\text { satisfaction as they accomplish organizational goals and } \\
\text { objectives }\end{array}$ & 4.83 & $\mathrm{O}$ & 0.18 & 3.43 & VS & 0.59 & 3.65 & VS & 0.75 \\
\hline $\begin{array}{l}\text { 4. Provides possible resources to subordinates in } \\
\text { decision-making authority }\end{array}$ & 4.81 & $\mathrm{O}$ & 0.18 & 3.57 & VS & 0.60 & 3.66 & VS & 0.78 \\
\hline $\begin{array}{l}\text { 5. Develops empathy to employees as a means of understanding } \\
\text { their needs to come up with their best }\end{array}$ & 4.85 & $\mathrm{O}$ & 0.16 & 3.77 & VS & 0.65 & 3.78 & VS & 0.87 \\
\hline $\begin{array}{l}\text { 6. Gives total freedom to the subordinates that each knows their } \\
\text { respective roles in the implementation of organization's } \\
\text { mission and vision }\end{array}$ & 4.87 & $\mathrm{O}$ & 0.16 & 3.77 & VS & 0.63 & 3.41 & S & 0.89 \\
\hline Grand mean & 4.84 & $\mathrm{O}$ & 0.08 & 3.62 & Vs & 0.25 & 3.56 & VS & 1.0 \\
\hline
\end{tabular}

Notes. $\mathrm{X}_{1}$-mean rating of SUC administrators; $\mathrm{X}_{2}-$ mean rating of middle level managers; $\mathrm{X}_{3}-$ mean rating of the SSC officers; $\mathrm{DE}$ - descriptive equivalent of the mean; $\mathrm{Sd}$ — standard deviation; $\mathrm{O}$ — outstanding; VS—very satisfactory; S—satisfactory.

Using the same table, the middle level managers gave lowest rating on the statement "helping their organizational members to attain their personal satisfaction as they accomplish organizational goals and objectives" with a mean rating of 3.43 which gave the SUC administrators a satisfactory rating. The middle level managers believed that personal satisfaction does not only come in the form of material benefits, but as well as on the thoughts that the administrators believed on the worth of the workers in the organization. Highest mean rating that the middle level managers gave to SUC administrators was 3.77 with a descriptive equivalent of very satisfactory. This rating was noted on two statements: develops empathy to employees on the purpose of understanding their needs to come up with their best; and gives total freedom to subordinates that each knows their respective roles in the implementation of organization's mission and vision. Result of this finding could be attributed to the result of the study which was discussed previously that SUC administrators were described in their late prime age. According to Anderson (2000), older leaders are more focused on the soft qualities of management and the human relations. They focused more of their management styles on unfolding potentialities of their subordinates and utilizing these potentialities not only to the good of the company, but also for the good of the employees. They also demonstrate an active concern for other people and their needs, forming close and supportive relations with them.

For the SSC officers, the items which received the lowest rating were noted on the item "gives members the flexibility to innovate, develop new processes, techniques" with a mean rating of 3.28. According to Bass (2000), "Transformational leaders are the front runners in bringing change to the entire organization". Transformational leadership is a way of bringing change that uplifts and benefits all in the entire organization. $\mathrm{He}$ is able to connect his true passion, intent, and inner wisdom in order to unlock their members' potential for the good of all. This is a clear indication that the young leaders maintain their expectations that SUC administrators were the leading front runners in motivating their followers to adopt measures of changes in the entire academe. Empowerment develops self-determination on the part of the followers for they can make their 
choices about what they do and how they can do and also develops strong sense of meaning for they believed that all their actions really contributed to the success of the entire organization.

Careful analysis of Table 7 reveals that the SUC administrators gave the highest mean rating of 4.86 interpreted as outstanding in utilizing multiple sources for feed backing on self-understanding. This implies that SUC administrators used varied techniques to know their strength and weaknesses. As the rule implies, one cannot be an effective leader if he or she does not understand himself/herself. Lowest rating was noted on the statement, developing unity and oneness through commonalities of diversities in experiences with a mean of 4.75. Perhaps this finding implies that this is the more complex part of the organization. It is very difficult to unite an organization whose members have different norms, background, experiences, values, and beliefs. It is very imperative for leaders to realize that they can play an active role in uniting their people in spite of these complexities.

Table 7

Transformational Leadership in Terms of Self-Understanding Skills as Perceived by the SUC Administrators, Middle Level Managers, and SSC Officers

\begin{tabular}{|c|c|c|c|c|c|c|c|c|c|}
\hline Transformational behavior skills & $\mathrm{X} 1$ & $\mathrm{DE}$ & $\mathrm{Sd}$ & $\mathrm{X} 2$ & $\mathrm{DE}$ & $\mathrm{Sd}$ & $\mathrm{X} 3$ & $\mathrm{DE}$ & Sd \\
\hline \multicolumn{10}{|l|}{ Self-understanding skills } \\
\hline $\begin{array}{l}\text { 1. Understands the impact of personal behavior on the working } \\
\text { environment and the control factors associated with attitude } \\
\text { and behavior }\end{array}$ & 4.83 & $\mathrm{O}$ & 0.15 & 3.31 & $\mathrm{~S}$ & 0.47 & 3.48 & $\mathrm{~S}$ & 0.79 \\
\hline $\begin{array}{l}\text { 2. Utilizes multiple source for feed backing on } \\
\text { self-understanding }\end{array}$ & 4.86 & $\mathrm{O}$ & 0.17 & 3.35 & $\mathrm{~S}$ & 0.47 & 3.87 & VS & 0.73 \\
\hline $\begin{array}{l}\text { 3. Builds greater levels of resilience, self-esteem, creativity, } \\
\text { initiative, and confidence }\end{array}$ & 4.83 & $\mathrm{O}$ & 0.17 & 3.32 & $\mathrm{~S}$ & 0.47 & 3.41 & S & 0.63 \\
\hline 4. Improves the consistency of positive behaviors & 4.85 & $\mathrm{O}$ & 0.70 & 3.42 & S & 0.44 & 3.04 & $\mathrm{~S}$ & 0.94 \\
\hline $\begin{array}{l}\text { 5. Enhances self-regulation and self-control in difficult } \\
\text { situations }\end{array}$ & 4.80 & $\mathrm{O}$ & 0.17 & 3.34 & $\mathrm{~S}$ & 0.46 & 3.41 & S & 1.12 \\
\hline $\begin{array}{l}\text { 6. Develops unity and oneness through commonalities of } \\
\text { diversities in experiences }\end{array}$ & 4.75 & $\mathrm{O}$ & 0.15 & 3.27 & S & 0.43 & 3.41 & $\mathrm{~S}$ & 1.01 \\
\hline Grand mean & 4.75 & $\mathrm{O}$ & 0.17 & 3.33 & $\mathrm{~S}$ & 0.46 & 3.43 & $\mathrm{~S}$ & 0.51 \\
\hline
\end{tabular}

Notes. $\mathrm{X}_{1}$-mean rating of SUC administrators; $\mathrm{X}_{2}-$ mean rating of middle level managers; $\mathrm{X}_{3}$-mean rating of the SSC officers; $\mathrm{DE}$ - descriptive equivalent of the mean; $\mathrm{Sd}$ — standard deviation; O—outstanding; VS—very satisfactory; S—satisfactory.

Using the same table, for the middle level managers, the highest rating was noted on "improves consistency of positive behaviours" with a mean rating of 4.42. The result implies that SUC administrators were looked up as the model in the organization. The positive behaviour manifested by the SUC administrators would also be creating a positive effect on the part of its constituents especially in terms of outputs. Lowest rating by this group was noted on "develops unity and oneness in the organization through commonalities of diversities in experiences" with a mean rating of 3.27 interpreted as satisfactory. This finding implies that SUC administrators have the responsibility of uniting his people in the presence of established interpersonal differences which has nothing to do with leadership competencies but the most difficult to deal with.

For the SSC officers, the lowest rating was noted on the item "improves consistency of positive behaviours" with a mean rating of 3.04, indicating a satisfactory performance. The lowest satisfactory rating implies that there were some instances that the SUC administrators were observed not fostering positive behaviour to this group of respondents. The positive behaviour will always have a domino effect on the people they dealt with, thus promoting positive result in the entire organization. This result may also serve as a 
reminder to them that in the academic organization, the SUC administrators were looked up as role model by the people they directly served. In the hierarchy of the organization, those who occupied the lower rank take their cue from their leaders, not from what is being said but what their leaders do.

Table 8 presents the effect of person related factor on transformational leadership of SUC presidents and vice-presidents, using Pearson's moment of correlation. Test of significance was further tested using t-test tabulated 1.96 at 0.05 level of significance.

Table 8

Effect of the Person Related Factor on Transformational Leadership

\begin{tabular}{lllll}
\hline Variables & $\mathrm{r}$ & Interpretation & t computed value & Remarks \\
\hline Gender & 0.085 & Very small effect & 0.45 & Insignificant \\
Age & 0.105 & Very small effect & 0.56 & Insignificant \\
Educational attainment & 0.039 & Very small effect & 0.21 & Insignificant \\
Faculty rank & 0.152 & Very small effect & 0.81 & Insignificant \\
Seminars attended & -0.143 & Very small negative effect & 0.76 & Insignificant \\
Membership to professional & 0.098 & Very small effect & 0.52 & Insignificant \\
organization & 0.24 & Moderately small effect & 3.66 & Highly significant \\
Relevant experience & 0.013 & Very small effect & 0.07 & Insignificant \\
Membership to civic organization & & &
\end{tabular}

Among the person related factor used in the study relevant experience was found to be significantly affecting the transformational leadership of SUC presidents and vice-presidents as noted by the coefficient correlation $\mathrm{r}$ of 0.24 , describing that the effect was moderately small with the equivalent $t$-computed value of 3.66 which is far greater than the t-tabulated value of 1.96 at 0.05 level of significant. The null hypothesis that person related factor has no effect on transformational leadership is denied in favor of the alternative hypothesis.

\section{Conclusions}

\section{Demographic Profile of Presidents and Vice-Presidents of State University and Colleges}

The president and vice-president of state-owned universities and colleges are in their prime age of 58 years old and were classified as older managers. They focused more of their management styles on unfolding potentialities of their subordinates and utilizing these potentialities not only to the good of the company, but rather for the good of the employees. They also minimize risk by studying current problems in the light of past practices and experiences. They also demonstrate an active concern for other people and their needs, forming close and supportive relations with them. Leadership of state-owned universities and colleges could be described as masculine. Only one lady president was noted in the study and the rest are male. However, in terms of educational qualifications, the female counterparts showed parity with their male counterparts, but in term of economic benefits, these female leaders were left behind. Similarly, Still (1997) viewed that education managers continue to define management in masculine terms. In general, most SUC administrators are highly qualified in terms of their educational qualification, for majority of them are doctors or $\mathrm{PhD}$ degree. This result could perhaps be attributed to the fact that educational requirements for university administrators must be holder of doctorate degree. Majority of the SUC leaders did not enjoy the rank of professors, and opted to receive their ranks as university president and vice-presidents because of higher salary rate. Furthermore, these SUC leaders still enjoined themselves from attending seminars and trainings that are found to be relevant to the 
position they are presently holding. They uphold that seminars and trainings would further develop their leadership skills in the context of life like situation. It would expose them to focus on strategic planning, public relations, and interpersonal skills. It would also improve their scientific attitudes and methodologies in finding better solutions to some organizational problems in the most effective and efficient ways. The SUC administrators had been in their post for a quite number of years, honing their skills and expertise as leaders of the institutions of learning.

\section{Transformational Leadership Behavior Skills of SUC Presidents and Vice-Presidents}

In terms of visioning skills, the SUC leaders were given the rating of very satisfactory. SUC administrators as transformational leaders manifest great influence in the formulation of the organization's mission and vision. Top management also leads in the formulation of the organization's vision and mission. Furthermore, SUC administrators will not only lead as front runners in the realization of the organization's mission and vision, but as well as utilize the full potentials of the work force in its aim to realize their goals. Welch (1997) emphasized that best leader does not provide a step by step instruction manual for workers. SUC administrators as transformational leaders need to assert more motivational skills to inspire their follower to perform their exacting duties and responsibilities toward the realization of whatever they aspire to accomplish in the end. SUC administrators create a favourable climate for fostering creativity need to use their power to encourage the open expression of ideas and to suppress uncooperative and/or aggressive reactions between members.

Similarly, the SUC leaders received a very satisfactory rating in their anticipating skill. SUC administrators as transformational leaders showed a strong view of the future. Their daily experiences showed that operational problems may occur and they need to provide control measures to minimize if not totally eradicate such occurrences. As transformational leaders who seek to solve problems, then it is imperative that they must demonstrate sincerity and commitment in finding effective and efficient solutions. They use every opportunity and whatever works to infect and re-infect their follower with a high level of commitment to solve future problems.

Another very satisfactory rating was received by the SUC leaders in their valuing skills. SUC administrators as transformational leaders put passion and energy into everything they do. They care about their people and want them to be successful. They carry their members as they also climb the ladders of success. Perhaps, the most important challenge to SUC administrators is to face a variety of challenges to their own value system and the value system of the people under their leadership. Interacting with individuals and groups, holding divergent and conflicting values will be an inevitable fact of life.

Similar rating of very satisfactory was received by the SUC leaders in terms of their empowering skills. SUC administrators in Region III need to exemplify in this area of transformational leadership because of the voluminous tasks right at the tip of their nose. Empowerment will not only free themselves from some of these tasks, but concentrate more of their precious time on matter that judiciously needs immediate attention. Delegation of tasks will also unfold unique potentialities of members to support their personal growth for that it will give them the opportunity to initiate problem solving, innovations, administrative, and decision-making. Delegation also strengthens the organization for one will be motivated to work, and signals that members are trusted and their development is important.

Also on self-understanding skills, the SUC leaders were given a very satisfactory rating. The SUC administrators were looked up to set the examples. In any organization, the other members in the organization 
take their cue from their leaders, not from what is being said but what their leaders do. As noted by Gunter (2001), he emphasized the importance of self-understanding on effective leadership. Nobody is able to lead and manage others unless they are able to understand themselves. Understanding oneself is the skills needed to correctly manage actions, words, demeanor, attitude, image, and its impact to others.

Of all the personal qualifications needed to select SUC leaders, the biggest emphasis must be on relevant experience. Crucially relevant work experience is an essential for some career area and a big advantage for most. Experience implies knowledge (Hughes, 2004). The longer the time a manager stays in the work place, it will enable him to master his line of craft by the heart. It exposes him to different opportunities of developing his skills not only to know the technical side of his work but more importantly to gain flexibility in dealing with people.

\section{References}

Abad, F. B. (2004). Key note speaker at 2004 National Educators Congress. Bacolod Convention Plaza Hotel, Bacolod City.

Abu-Duhou, I. (1999). School-based management. Paris: UNESCO/IIEP.

Anderson, J. (2000). Factors that influence the satisfaction for students affairs administrators. In L. S. Hagedorn (Ed.), New directions for institutional research. San Francisco: Jossey.

Avollo, B., \& Bass, B. M. (1993). Transformational leadership and performance: A longitudinal investigation. The Leadership Quarterly, 4(1), 81-102.

Bass, B. M. (1990). From transactional to transformational leadership: Learning to share the vision. Organizational Dynamics, $18(3), 19-31$.

Bass, B. M. (2000). The future of leadership in learning organization. Journal of Leadership and Studies, 7(3), 18-40.

Bass, B. M., \& Yamarino, A. D. (1990). Transformational leadership and the falling dominoes effect. Group and Organization Management, 12(1), 73-87.

Bowman, J. (1999). Performance appraisal: Verisimilitude trumps veracity. Public Personnel Management, 28(4), 557-576.

Bryant, S. E. (2003). The role of transformational and transactional leadership in creating, sharing and exploiting organizational knowledge. Journal of Leadership and Organizational Studies, 9(4), 32-44.

Byrd, R. E. (1987). Corporate leadership skills: A new synthesis. Organizational Dynamics, 16(2), 34-43.

Cable, D. M., \& Judge, A. T. (1996). Person-organization fit, job choice decisions, and organization entry. Organizational Behavior and Human Decision Processes, 67(3), 294-311.

Cushman, P., \& Cahn, D. (1995). Communicating organizational change: A management perspective. New York: State University New York Press.

Dickenson, N. S., \& Perry, R. E. (2000). Factors influencing the retention of specially educated public child welfare workers. Journal of Health and Social Policy, 15(3-4), 89-103.

Dumond, E. J. (2000). Value management: An underlying framework. International Journal of Operations and Production Management, 20(9), 1062-1077.

Eagly, A. H., \& Carli, L. L. (2003). The female leadership advantage: An evolution of the evidence. The Leadership Quarterly, 14(6), 807-834.

Edwards, Jr., \& Cable, D. M. (2009). The value of value congruence. Journal of Applied Psychology, 94(3), 654-677.

Findley, B., \& Findley, D. (1992). Effective schools: The role of the principal. Contemporary Education, 63(2), 102-104.

Frazier, A. (1997). A road map for quality transformation in education. Boca, Raton, FL: St. Lucie Press.

Gardner, J. W. (1990). On leadership. New York, NY: The Free Press.

Geneva survey on gender equality. (2008, November 13). Philippine Star Newspaper, p. 8.

Gunter, H. (2001). Leaders and leadership in education. London: Sage Publication.

Hernez-Broom, G., \& Hughes, R. L. (2004). Leadership development: Past, present and future. Human Resource Planning, 27(1), 24-32.

Hogan, R. T., \& Warrenfeltz, R. (2003). Educating the modern manager. Academy of Management Learning and Education, 2(1), 74-84.

Hughes, C. (2004). Krikie: Names, necessity and identity. Oxford: Oxford University Press. 
Katzenbach, J. R., \& Smith, D. K. (2005). The discipline of team. Harvard Business Review.

Kotelnikov, V. (2007). Employee empowerment: Harvesting the creative and emotional power of all your people. Retrieved from http://ventures.powweb.com/business_guide/crosscuttings/employee_empowerment.html

Kotter, J. P. (1999). What leaders really do. Boston: Harvard Business School Press.

Malka, A., \& Chatman, J. (2003). Intrinsic and extrinsic work orientations as moderators of the effect of annual income on subjective well-being: A longitudinal study. Personality and Social Psychology Bulletin, 29(6), 737-746.

Marguilles, J. E. (2004). Performance appraisals. Retrieved from http://www.bnabooks.com

Morgan, C., \& Murtgatrod, S. (1993). Total quality and the school. Buckingham: Open University Press.

Northouse, P. G. (2004). Leadership theory and practice (3rd ed.). London: Sage Publications, Inc.

Philippine Commission on Educational Reform (PCER) Report. (2009). Retrieved from http://members.tripod.com/ pcer_ph/id19.htm

Rynes, S. L., Bartunek, J. M., \& Daft, R. L. (2001). Across the great divide: Knowledge creation and transfer between practitioners and academics. Academy of Management Journal, 44(2), 340-355.

Sallis, E. (2002). Total quality management in education (3rd ed.). Great Britain: Kogan Page Ltd.

Shah, T., \& Brenan, J. L. (2000). Managing total quality in higher education: An institutional perspective on international change and assessment and change. Buckingham: Open University Press.

Still, L. V. (1997). Glass ceilings and sticky floors. Barriers to the career of women in the Australian finance industry. A report prepared for Human Rights and Equal Opportunity Commission and Westpac, Edith Cowan University. Retrieved from http://www.humanrights.gov.au/sites/default/files/content/pdf/sex_discrim/glass_ceilings.pdf

Student hand book. (2010). Balanga City: Bataan Peninsula State University.

Thalner. D. M. (2005). The practice of continuous improvement in higher education. Unpublished dissertation, University of Michigan, Kalmazoo, Michigan.

Vecchio, R. P., \& Boatwright, K. J. (2002). Preferences for idealized styles of supervision. Leadership Quarterly, 13(4), $327-342$.

Wagner, S., Parker, C. P., \& Christiannsen, N. (2003). Employers that think and act like owners: Effects of ownership, beliefs and behaviors on organizational effectiveness. Personnel Psychology, 56, 847-871.

Welch, J. (1997). Speech: General electric annual meeting. Charlotte, NC.

Womacks, J. P., \& Jones, D. T. (2003). Lean thinking: Banish waste create wealth in your corporation. UK: Simon and Schuster.

Yorges, S. L., Weiss, H. M., \& Strictland, O. J. (1999). The effect of leader outcomes on the influence, attributions, and perceptions of charisma. Journal of Applied Psychology, 84, 428-436. 